\title{
Opinion \\ Cognitive Function and Neuropsychiatric Disorders after COVID-19: A Long Term Social and Clinical Problem?
}

\author{
José M. Ramírez-Moreno ${ }^{1, * \mathbb{C}}$, Agustín Muñoz-Sanz ${ }^{2}$ and Francisco J. Vaz-Leal ${ }^{3}$ \\ 1 Neurology Area, Biomedical Sciences Department, Faculty of Medicine and Health Sciences, \\ Extremadura University, 06006 Badajoz, Spain \\ 2 Infectious Diseases Area, Biomedical Sciences Department, Faculty of Medicine and Health Sciences, \\ Extremadura University, 06006 Badajoz, Spain; infectio@unex.es \\ 3 Psychiatry Area, Medical-Surgery Therapeutics Department, Faculty of Medicine and Health Sciences, \\ Extremadura University, 06006 Badajoz, Spain; fjvaz@unex.es \\ * Correspondence: jramrez@unex.es
}

Citation: Ramírez-Moreno, J.M.; Muñoz-Sanz, A.; Vaz-Leal, F.J. Cognitive Function and Neuropsychiatric Disorders after COVID-19. A Long Term Social and Clinical Problem? BioMed 2022, 2 50-59. https://doi.org/10.3390/ biomed2010005

Academic Editor: Kumar Vaibhav

Received: 20 December 2021

Accepted: 20 January 2022

Published: 24 January 2022

Publisher's Note: MDPI stays neutral with regard to jurisdictional claims in published maps and institutional affiliations.

Copyright: (C) 2022 by the authors. Licensee MDPI, Basel, Switzerland. This article is an open access article distributed under the terms and conditions of the Creative Commons Attribution (CC BY) license (https:// creativecommons.org/licenses/by/ $4.0 /)$.

\begin{abstract}
SARS-CoV-2 is one more virus that can affect the brain in one way or another. Now, we are only beginning to understand some mechanisms and the degree to which it can impact the nervous system. Considering the rapid accumulation of knowledge about multiple neurological and cognitive symptoms in COVID-19 patients, it seems useful to encourage the development of systematic approaches for the diagnosis, management and treatment of the cognitive aspects of COVID-19. From what is known at this time about the impact of COVID-19 on the brain, the presentation of long-term cognitive sequelae can be expected to be heterogeneous in nature and will depend at least in part on the severity of the disease at the stage acute COVID-19. The long-term essential characteristics of these sequelae will probably be related to a combination of causes and different neuropathological processes in the acute phase. The scope and severity of the current COVID-19 pandemic are unparalleled in modern society. The later implications for neurological function can be just as serious. Although the current focus is on the management of acute diseases, in the near future the focus should be on the long-term consequences of COVID-19 infection and its mitigation, hence the need for the development of systematic approaches for the management of the cognitive and neuropsychiatric aspects of COVID-19.
\end{abstract}

Keywords: COVID-19; cognition; neuropsychiatric disease; pathogenic mechanisms; long-term; outcome

\section{Introduction}

In late December 2019, Chinese health authorities reported a cluster of pneumonia cases due to a new coronavirus species (which quickly came to be known as SARS-CoV-2). This RNA virus is responsible for coronavirus disease-2019 (COVID-19). Since then, the number of persons affected skyrocketed and spread throughout the world. Four months later, on 11 March, the World Health Organization (WHO) resolved to declare the outbreak of a pandemic because of the global epidemiological situation. As of 12 December 2021, the WHO has reported over 269 million laboratory-confirmed positive cases and nearly 5.3 million deaths worldwide [1].

From a clinical perspective, approximately $80 \%$ of patients develop only a few or no symptoms ( $40 \%$ of the infected are asymptomatic). Additionally, SARS-CoV-2 infection primarily affects the respiratory system, with fever and cough being the first and most usual acute manifestations in symptomatic subjects [2,3]. Around $15-20 \%$ of affected may suffer a much more severe illness, with respiratory complications potentially fatal in $5 \%[4,5]$. Likewise, it can lead to several kinds of systemic neurological manifestations [6].

They include non-specific and mild symptoms, mainly headache, myalgia, anosmia and dysgeusia. However, some patients can develop more severe complications such as a neuroinflammatory syndrome, meningoencephalitis, encephalopathy, cerebrovascular 
disease, or polyradiculoneuritis (i.e., Guillain-Barré syndrome) [6-9]. Usually, seriously ill patients exhibit the severe neurological manifestations with more frequency [10]. In a large cohort (841 patients) hospitalized by COVID-19 from two Spanish hospitals, 55\% had neurological symptoms, a rate that increased to $65 \%$ in those with more serious infections [11]. CNS involvement was more frequent than PNS compromise [12]. Potential explanations include increased brain vulnerability to compared to peripheral nerves and specific mechanisms by which SARS-CoV-2 may affect the nervous system are still debatable.

Several systematic and narrative reviews have been published that present a complete overview of the scientific literature on the involvement of the central and peripheral nervous system by COVID-19 and the various manifestations in clinical terms and paraclinical findings [13,14]. Additionally, the authors have made an effort to comprehensively assess pathophysiology and categorize clinical features, as well as neuropathology, neuroimaging, electrophysiology, and CSF findings together, to analyze their impact on the clinical setting [13].

COVID-19 commonly affects people of all ages, but the elderly population is disproportionately affected. Therefore, hospitalization and mortality rates increase, notably for those above the age 65 [15]. Current evidence indicates that age, male sex and the presence of several specific comorbidities are factors of poor prognosis and increased risk of death $[16,17]$. In addition to vulnerability and suffering a more severe disease, the older population is in increasing danger of sequelae.

A recent literature review highlighted the nervous system involvement of SARS$\mathrm{CoV}-2$ infection with respect to its diverse neurological presentation and concludes, since most reports and studies primarily emphasize respiratory symptoms, the prevalence of neurological sequelae of COVID-19 could be underestimated [14].

The total spectrum of long-term evolutive complications in COVID-19 surviving patients is unknown. However, as occurs in other viral infections and critical-illness survivors, there is increasing evidence that patients with COVID-19 can present neurological sequelae in the months or years after the acute infection. In this sense, neuropsychiatric disorders or cognitive deficits are the more common problems [18-20].

According to the previous premises, it could be appropriate to evaluate COVID-19's neuropsychiatric and cognitive manifestations, especially when direct social and clinical consequences can arise on the quality of life of the subjects who suffer from them.

\section{Discussion}

\subsection{COVID-19 Neuropsychiatric Manifestations}

There are multiple neuropsychiatric manifestations described in patients infected with SARS-CoV-2. They include insomnia, anxiety, stress symptoms, psychosis, and mood disorders [11,21-23]. Data obtained from a collaborative global health platform, which included medical records of over 40,000 positive COVID-19 cases, have shown that $22.5 \%$ had one or more neurological or psychiatric manifestations. Anxiety and mood disorders were the most prevalent (4.6\%) conditions [24]. A UK study showed that 39 cases of a cohort of 125 patients presented neuropsychiatric presentations: disturbed mental state, encephalopathy, or new-onset psychosis [25].

A retrospective study carried out in a Spanish hospital identified 10 patients with newonset psychotic symptoms amongst 10,000 persons with laboratory-confirmed coronavirus infection. The psychiatric symptoms resolved in less than 2 weeks after diagnosis. Those episodes were considered "atypical", considering the age of onset, the rapid recovery and the absence of a family history of psychiatric disorders, including substance use/abuse [26].

Moreover, seriously ill COVID-19 patients admitted to an Intensive Care Unit (ICU) also have a higher risk of developing delirium, aggravated by the frequent need for high doses of sedation drugs, advanced age, and the presence of comorbidities [27]. In a French study, 40 out of 58 patients (69\%) treated in an ICU showed agitation, and 26 of them developed a confused state. Brain imaging tests showed relevant alterations, such as bilateral frontotemporal hypoperfusion [28]. 
There is also evidence of a greater prevalence of depressive symptoms in the subjects recovered from COVID-19 [29,30]. In Shenzhen (China), a study including 126 convalescents subjects showed that self-reported depression and anxiety were prevalent after hospital discharge [29]. There is an association between depression and a state of systemic immune suppression [30].

Most of the findings described are from self-reported scales, without formal clinical evaluations. In our opinion, it is necessary to use more robust and follow-up studies to determine whether the neuropsychiatric symptomatology of COVID-19 patients is related to the infection itself, and, also, to know if they are secondary to the immune response, adverse drug effects or psychological stressors. Whether the symptoms improve, disappear, remain, worsen or reappear over time, and, finally, the possible impact on the subjects who present them are also relevant areas of studies.

\subsection{COVID-19 Cognitive Manifestations}

As far as we know, there are only a few studies analyzing the effect of COVID-19 on cognitive function. Data from over 430,000 participants in the UK's biobanks reveal several psychosocial factors associated with the risk of hospitalization by COVID-19. After controlling for variables that may introduce bias (demographic, economic, social, psychological, lifestyle factors, and comorbidities), the only significant factor associated with hospitalization risk was lower cognitive function [31], however, the causality and probable mechanisms involved in such an association are unclear. In a retrospective study conducted in Chicago (USA) on 50 patients hospitalized for COVID-19 with neurological symptoms, $24 \%$ presented short-term memory loss [32]. Another study from the UK found that 6 out of a cohort of 125 patients hospitalized by COVID-19 and neurological manifestations presented a neurocognitive disorder [25].

There are also signs of cognitive dysfunction after discharge from the hospital. In this sense, a French observational study showed that more than a third $(15 / 45)$ of patients discharged from ICU presented cognitive deterioration, especially of the dysexecutive syndrome [28]. In a small series of four patients with severe COVID-19 requiring ICU admission, all of them had cognitive impairment (memory deficits and frontal syndrome) after discharge. It is exciting to know that the symptoms remitted after intravenous immunoglobulin therapy [33]. Additionally, there was an association between the emergence of delirium during hospitalization for COVID-19 and a lower score in cognitive tests four weeks after discharge, although the comparison between groups did not reach statistical significance by a long way [5].

The lack of more accurate information about cognitive symptoms in patients with COVID-19 may explain the pandemic's impact on health systems and the difficulty of performing a comprehensive neuropsychological assessment in this context. However, the study of cognitive function in these subjects is of great value to identify the factors associated with the risk of the appearance of cognitive symptoms in people without preexisting cognitive impairment and to increase certainty about the possible underlying mechanisms. It is fundamental and urgent to minimize the possible adverse effects on the survivors' cognitive and psychosocial functioning and quality of life.

\subsection{Long-Term Neuropsychiatric and Cognitive Manifestations}

There is not enough evidence for the long-term complications in patients who survive the disease. Even so, it is not unreasonable to expect that they will appear in the future (months or years later of the acute infection), as observed in 3 of 20 past pandemics caused by influenza virus and in two epidemic coronaviruses (MERS-CoV and SARS-CoV) [34,35], and in survivors of those who needed ICU admission $[19,20]$. In a systematic review and meta-analysis [34] of 72 studies concerning neuropsychiatric manifestations secondary to coronavirus infection, including the SARS-CoV $(n=47)$, MERS-CoV $(n=13)$, and the current SARS-CoV-2 $(n=12)$ [34], both SARS-CoV and MERS-CoV were associated with neuropsychiatric symptoms in both the acute and recovery phases. The results of the meta- 
analysis showed that, after recovery, the estimated prevalence of post-traumatic syndrome was $32.2 \%$ (mean follow-up: 33.6 months), and the prevalence of anxiety disorders and depression was 15\% (average follow-up of 11.6 and 22.6 months, respectively) [34].

According to a recent meta-analysis, the health-related quality of life was significantly lower in patients compared to the control group [34]. However, many of the studies included in the analysis were of low or medium quality due to limited evaluation of psychiatric symptoms and the lack of a control group [34]. However, the results of one of the studies, with a sample of 181 individuals infected by SARS-CoV-1, showed that while only $3.3 \%$ of patients had a history of psychiatric disorders before the viral infection, after an average follow-up of 3.4 years, $42.5 \%$ met clinical criteria for at least one psychiatric illness (an increase of 39.2 points). Stress disorder was the most prevalent disorder (54.5\%), followed by depression (39\%) [18]. Likewise, 71\% of confirmed MERS-CoV cases developed psychiatric symptoms, and $40 \%$ of them met the criteria with a clinical psychiatric diagnosis during hospitalization. None of the subjects quarantined as possible cases who tested and tested negative for the virus showed psychiatric symptoms [36]. Therefore, this evidence suggests a possible etiological role for coronavirus in inducing brain changes related to psychiatric symptoms.

In persons with acute respiratory distress syndrome (ARDS) admitted to the ICU, the following risk factors were associated with cognitive impairment: orotracheal intubation/mechanical ventilation, aggressive treatments, and prolonged sedation [37]. In the current SARS-CoV-2 pandemic, an Italian retrospective case series study of 1591 patients admitted to the ICU found $88 \%$ of patients required mechanical ventilation [38]. Long-term outcome data on adults who require this respiratory help generally show alterations in several cognitive domains, including attention, memory, verbal fluency, processing speed, or function executive at the follow-up after discharge $[20,39,40]$.

The latest studies carried out provide sufficient evidence to support the hypothesis that COVID-19 infection is associated with cognitive deficits that persist in the recovery phase [41,42]. Regarding the cognitive profiles, the global data indicate that the deficits affected multiple domains to varying degrees, being more pronounced in reasoning, problem solving, spatial planning, and goal sensing, while simpler functions such as working memory and emotional processing are respected [42-44]. Additionally, the possible limitations related to inferences about cause and effect should be considered when the studies are cross-sectional [41]. These results are consistent with reports of post-acute COVID syndrome, where "brain fog," difficulty concentrating, and difficulty finding the right words are common [42]. It is also important to be cautious in inferring a neurobiological or psychological basis for the observed deficits without the availability of appropriate neuroimaging data in many of these works, even though it can be assumed that there is damage to the brain's structural network [41]. The study of the cognitive and social consequences of this pandemic must be deepened, to better plan the treatment and rehabilitation of these patients. Quite possibly, these patients with COVID-19 could benefit from early and personalized neuropsychological rehabilitation and some studies in this regard are beginning to be published [45].

\subsection{Possible Pathogenic Mechanisms}

The underlying causes of neurological COVID-19-related symptoms and the mechanisms involved in cognitive impairments are not fully understood. The etiology is probably multifactorial. Some factors include virus neurotropism, a systemic inflammatory response to the virus, cerebrovascular ischemia due to endothelial dysfunction (or coagulopathy), ARDS in more severe cases, invasive ventilation and sedation, the adverse effects of some drugs used to treat COVID-19 [37], and some genetic variants.

We now discuss three of the most probable potential pathogenic mechanisms: (1) viral neurotropism; (2) systemic inflammatory response; (3) P2 $\times 7$ receptor roles in COVID-19 processes and (4) genetic variants. 
(1). Viral neurotropism: Similar to other coronaviruses, SARS-CoV-2 shows neurotropism or an invasion of the Central Nervous System (CNS). Human coronaviruses share a substantial similarity with neuro-invasive animal coronaviruses, such as PHEV (Porcine hemagglutinating encephalomyelitis virus), FCoV (Feline Coronavirus), and JHM (Murine hepatitis virus), regarding the structure and replication mode. All animal coronaviruses can invade the nervous system and cause multiple neurological disorders. Of the seven human coronaviruses reported until now, four (HCoV-229E, HCoV-OC43, SARS$\mathrm{CoV}$, and MERS-CoV) are neuro-invasive in humans [46]. Two potential factors explain coronavirus's intracerebral spread, namely, a direct hematogenous attack and a retrograde invasion through the upper respiratory tract [47]. On mammalian host cells, SARS-CoV-2 uses the spike protein (S protein) located on its surface to bind to the Angiotensin-2 Converting Enzyme (ACE2) receptor [48]. The ACE2 receptor is known to be expressed in neurons and glial cells [49].

On the other hand, in some animal models, there is evidence of neuronal death in the brain after SARS-CoV-1 infection, a pathogenic occurring through the olfactory bulb [50]. To date, there is little evidence of brain infection directly related to the SARS-CoV-2. The initial evidence of CNS damage related to COVID-19 emerged when a SARS-CoV-2-infected patient was diagnosed with acute necrotizing hemorrhagic encephalopathy, along with other common symptoms of COVID-19. Brain MRI images showed hemorrhagic edges in several brain segments, such as the bilateral thalamus, medial temporal lobes, and sub-insular regions [51]. A systematic review including 26 neuroimaging studies found that $34 \%$ of patients (124 out of 361 cases) presented lesions; the most frequent radiological finding was the diffuse affectation of the brain (subcortical and deep white matters), an injury attributable to COVID-19. Other common, though less prevalent, findings were microhemorrhages, hemorrhages, and cerebral infarctions [52]. The Reverse TranscriptionPolymerase Chain Reaction studies of cerebrospinal fluid samples performed in a few cases of COVID-19 with neurological manifestations were negative [28,33].

In contrast to the multitude of studies that have highlighted lung injure caused by COVID-19, less attention has been paid to the involvement of other organs in this systemic disease, including neuropathological issues [53]. Studies conducted so far to investigate the histopathological features of COVID-19 do not appear to have led to any specific damage to brain tissue caused directly by the virus itself. The available neuropathological data of COVID-19 cases are scarce, but most show hypoxic changes and demyelinating lesions, and these neuropathological findings seem to be related to systemic inflammation and coagulopathy caused by the infection, rather than to a direct effect of the virus $[54,55]$. However, a series of autopsies performed in Germany detected a viral load of SARS-CoV-2 in the brain, although at much lower levels than in the respiratory system [56].

At the moment, a consensus has by no means emerged about what exactly occurs during a viral invasion of the brain and the search for definitive evidence of SARS-CoV-2 infecting neurons is controversial.

(2). Systemic inflammatory response: Even without direct brain infection, a severe systemic infection can also cause a neuroinflammatory response. This reaction may promote further tissular brain damage $[57,58]$. In severe cases, the virus can trigger a host response that is exacerbated and dysregulated (cytokine storm), involving Tumor Necrosis Factor (TNF), and Interleukin-6 (IL-6), among other cytokines. If the response persists over time, it creates a systemic inflammation disorder, resulting in a disruption of the blood-brain barrier and neuronal cell damage. Current evidence related to SARS-CoV-2 shows that the most severely affected patients had higher proinflammatory cytokines levels $[59,60]$. Ultimately, the invasion of peripheral inflammatory molecules into the CNS can activate resident macrophages in the brain, that is, the microglia cell. This neural cell becomes hyperactivated and begins to produce its own set of inflammatory molecules, which enhance neuroinflammation. The whole process of preparing the microglia to act is known as "Microglial Priming" [61]. It is known that most classical chronic neurodegenerative diseases have an association with the so-called neuroinflammation. These diseases are 
Alzheimer's disease, multiple sclerosis, Parkinson's disease, Huntington's disease, and cerebrovascular disease [62].

Many researchers have tried to explain the phenomenon of "Microglial priming", in which the microglial multiplies and activates while remaining in this condition ("priming") for a long time. The "priming" makes the microglia exceptionally vulnerable to a secondary inflammatory stimulus. Even a small molecular trigger can induce an exaggerated microglia inflammatory response. Some experiments validated that TNF-alpha and microglial activation have a loop relationship with positive feedback. This mechanism explains why the brain is susceptible to cytokine storms created by any route, whether bacterial, viral, or because of other inflammatory abnormality related to aging. Thus, the cytokines produced by prepared microglia represent a much more significant threat to a disruption of the CNS homeostasis than the aggregated systemic inflammatory molecules of peripheral monocytes [62]. The secondary stimulus that activates the microglia can begin in the CNS by any means, similar to any other neuroviral or bacterial invasion. However, some conditions that contribute to systemic inflammation (for example, diabetes, vascular conditions, or arthritis) are the leading causes of "priming" of the microglia, a fact which can be observed mainly in older populations [63]. This situation puts the older population at a greater risk of neurological and cognitive disabilities after exposure to viral respiratory infections.

As has been said before, chronic systemic inflammation is one of the underlying pathogenic mechanisms involved in some neurodegenerative conditions, such as Alzheimer's disease (AD) [64]. In a sample of 12,336 participants (mean age, 56.8 years), there was a significant association between systemic inflammation and fast cognitive impairment (after a 20-year follow-up) [63]. Inflammation related to viral infection worsens tau-related pathologies, resulting in spatial memory impairment [64]. The hippocampus, a cerebral region involved in memory formation, is particularly vulnerable to respiratory viral infections, as demonstrated in model animals [65]. For example, in mice infected with the influenza virus, a two-class deterioration was observed, namely, short-term hippocampus-dependent learning and long-term spatial memory impairment [66]. Besides, in the presence of proinflammatory cytokines, microglial cells lose their ability to phagocytize the $\beta$-amyloid, a pathogenic mechanism perhaps related to the amyloid accumulation plaques that are characteristics of AD [67]. The cerebral hypoperfusion observed in the SARS-CoV-2 infection may accelerate amyloid- $\beta$ aggregation and deposition, [68] and the aggregation and abnormal folding of such other proteins as tau, TDP-43, and $\alpha$-synuclein [69]. It has also been suggested that the virus may induce the functional inhibition of acetylcholine receptors and promote dysregulation of the excitatory-inhibitory balance [70].

(3). The role of the P2 $\times 7$ receptor in COVID-19 infection: The P2 $\times 7$ receptor is expressed on CNS cells, mainly microglia and oligodendrocytes [71]. Elevated levels of extracellular ATP induced by SARS-CoV-2 infection can trigger hyperactivation of P2 $\times 7$ receptors leading to stimulation of the NLRP3 inflammasome as a key mediator in neuroinvasion and resulting neuroinflammatory processes, as has been observed in different psychiatric disorders (anxiety disorders, depression or bipolar disorder) and some neurodegenerative diseases (amyotrophic lateral sclerosis, Parkinson's or Alzheimer's disease) $[72,73]$. The hyperstimulation of the neuroimmune response observed during viral infection and in brain disorders may be mediated by the activation of the $\mathrm{P} 2 \times 7$ receptor; furthermore, this receptor appears as a key intermediary of the neuroinflammatory way as a possible consequence of SARS-CoV-2 infection [74]. As some authors argue, these facts may be of great interest, since the $\mathrm{P} 2 \times 7$ receptor antagonist would be a promising strategy to prevent or treat neurological complications in COVID-19 patients [74,75].

(4). Genetic variants: APOE- $\varepsilon 4$ gene allele, the most potent genetic risk factor for $\mathrm{AD}$, appears related to an increased risk of infection and mortality from COVID-19. The biological mechanisms involved in this association are not yet known [76]. There is a reduction of expression of ACE2 in the brain tissue in patients with $\mathrm{AD}$, particularly in those who carry an APOE allele $\varepsilon 4$. The ACE2 reduction correlates negatively with the 
pathology $\mathrm{A} \beta$ and tau phosphorylated [77]. Some authors argue that certain viral infections can exacerbate neurodegeneration in subjects with susceptible genetic variants.

\section{Conclusions}

Based on the preliminary evidence explored in this short review about COVID-19 posinfectious associated neuropsychological and cognitive disorders, we think more studies are necessary. It is crucial to determine the actual magnitude of the problem, from biological mechanisms to social consequences [78]. The underlying causes of the symptoms, the pathogenic mechanisms involved in lasting damage, and whether the new pandemic coronavirus could precipitate, or exacerbate, some classical neurodegenerative diseases have been investigated. The pandemic raises the prospect of growing collaborations between neurosciences disciplines and virologist. It is a reminder that the brain, notwithstanding the blood-brain barrier, is by no means impenetrable. Understanding the distinctive ways that viruses can access in and wreak havoc to the brain may draw growing interest. This is a great problem, and we think this is going to become a major area of study.

Author Contributions: J.M.R.-M., A.M.-S. and F.J.V.-L. contributed equally to the conceptualization, writing, preparation of the original draft, writing of the review, and final editing of the manuscript. All authors have read and agreed to the published version of the manuscript.

Funding: This research received no external funding.

Institutional Review Board Statement: Ethical review and approval were waived for this study.

Informed Consent Statement: Not applicable.

Conflicts of Interest: The authors declare no conflict of interest.

\section{References}

1. World Health Organization. Weekly Epidemiological Update on COVID-19-14 December 2021. 2021. Available online: https:/ / www.who.int/publications/m/item/weekly-epidemiological-update-on-covid-19---14-december-2021 (accessed on 17 December 2021).

2. Borges do Nascimento, I.J.; Cacic, N.; Abdulazeem, H.M.; von Groote, T.C.; Jayarajah, U.; Weerasekara, I.; Esfahani, M.A.; Civile, V.T.; Marusic, A.; Jeroncic, A.; et al. Novel Coronavirus infection (COVID-19) in humans: A scoping review and meta-analysis. J. Clin. Med. 2020, 9, 941. [CrossRef] [PubMed]

3. Lechien, J.R.; Chiesa-Estomba, C.M.; Place, S.; van Laethem, Y.; Cabaraux, P.; Mat, Q.; Huet, K.; Plzak, J.; Horoi, M.; Hans, S.; et al. Clinical \& epidemiological characteristics of 1420 European patients with mild-to-moderate coronavirus disease 2019. J. Intern. Med. 2020, 288, 335-344. [PubMed]

4. $\mathrm{Wu}, \mathrm{Z} . ; \mathrm{McGoogan}, \mathrm{J.M}$. Characteristics of and Important Lessons from the Coronavirus Disease 2019 (COVID-19) Outbreak in China: Summary of a Report of 72314 Cases from the Chinese Center for Disease Control and Prevention. JAMA 2020, 323, 1239-1242. [CrossRef]

5. McLoughlin, B.C.; Miles, A.; Webb, T.E.; Knopp, P.; Eyres, C.; Fabbri, A.; Humphries, F.; Davis, D. Functional and cognitive outcomes after COVID-19 delirium. Eur. Geriatr. Med. 2020, 11, 857-862. [CrossRef] [PubMed]

6. Tsai, S.-T.; Lu, M.-K.; San, S.; Tsai, C.-H. The Neurologic Manifestations of Coronavirus Disease 2019 Pandemic: A Systemic Review. Front. Neurol. 2020, 11, 498. [CrossRef] [PubMed]

7. Ellul, M.A.; Benjamin, L.; Singh, B.; Lant, S.; Michael, B.D.; Easton, A.; Kneen, R.; Defres, S.; Sejvar, J.; Solomon, T. Neurological associations of COVID-19. Lancet Neurol. 2020, 19, 767-783. [CrossRef]

8. Paterson, R.W.; Brown, R.L.; Benjamin, L.; Nortley, R.; Wiethoff, S.; Bharucha, T.; Jayaseelan, D.L.; Kumar, G.; Raftopoulos, R.E.; Zambreanu, L.; et al. The emerging spectrum of COVID-19 neurology: Clinical, radiological and laboratory findings. Brain 2020, 143, 3104-3120. [CrossRef]

9. Román, G.C.; Spencer, P.S.; Reis, J.; Buguet, A.; Faris, M.E.A.; Katrak, S.M.; Láinez, M.; Medina, M.T.; Meshram, C.; Mizusawa, H.; et al. The neurology of COVID-19 revisited: A proposal from the Environmental Neurology Specialty Group of the World Federation of Neurology to implement international neurological registries. J. Neurol. Sci. 2020, 414, 116884. [CrossRef]

10. Pinzon, R.T.; Wijaya, V.O.; Buana, R.B.; Al Jody, A.; Nunsio, P.N. Neurologic Characteristics in Coronavirus Disease 2019 (COVID-19): A Systematic Review and Meta-Analysis. Front. Neurol. 2020, 11, 565. [CrossRef]

11. Romero-Sánchez, C.M.; Díaz-Maroto, I.; Fernández-Díaz, E.; Sánchez-Larsen, Á.; Layos-Romero, A.; García-García, J.; González, E.; Redondo-Peñas, I.; Perona-Moratalla, A.B.; Del Valle-Pérez, J.A.; et al. Neurologic manifestations in hospitalized patients with COVID-19: The ALBACOVID registry. Neurology 2020, 95, e1060-e1070. [CrossRef] 
12. Anand, H.; Ende, V.; Singh, G.; Qureshi, I.; Duong, T.; Mehler, M.F. Nervous System-Systemic Crosstalk in SARS-CoV-2/COVID19: A Unique Dyshomeostasis Syndrome. Front. Neurosci. 2021, 15, 727060. [CrossRef] [PubMed]

13. Guerrero, J.I.; Barragán, L.A.; Martínez, J.D.; Montoya, J.P.; Peña, A.; Sobrino, F.E.; Tovar-Spinoza, Z.; Ghotme, K.A. Central and peripheral nervous system involvement by COVID-19: A systematic review of the pathophysiology, clinical manifestations, neuropathology, neuroimaging, electrophysiology, and cerebrospinal fluid findings. BMC Infect. Dis. 2021, 21, 1-15. [CrossRef] [PubMed]

14. Harapan, B.N.; Yoo, H.J. Neurological symptoms, manifestations, and complications associated with severe acute respiratory syndrome coronavirus 2 (SARS-CoV-2) and coronavirus disease 19 (COVID-19). J. Neurol. 2021, 268, 3059-3071. [CrossRef] [PubMed]

15. Goujon, A.; Natale, F.; Ghio, D.; Conte, A.; Dijkstra, L. Age, Gender, and Territory of COVID-19 Infections and Fatalities; EUR 30237 EN.; Publications Office of the European Union: Luxembourg, 2020.

16. Lu, L.; Zhong, W.; Bian, Z.; Li, Z.; Zhang, K.; Liang, B.; Zhong, Y.; Hu, M.; Lin, L.; Liu, J.; et al. A comparison of mortality-related risk factors of COVID-19, SARS, and MERS: A systematic review and meta-analysis. J. Infect. 2020, 81, e18-e25. [CrossRef]

17. Martín-Sánchez, F.J.; Del Toro, E.; Cardassay, E.; Carbó, A.V.; Cuesta, F.; Vigara, M.; Gil, P.; Picado, A.L.L.; Valero, C.M.; Miranda J.D.; et al. Clinical presentation and outcome across age categories among patients with COVID-19 admitted to a Spanish Emergency Department. Eur. Geriatr. Med. 2020, 11, 829-841. [CrossRef]

18. Lam, M.H.B.; Wing, Y.K.; Yu, M.W.M.; Leung, C.M.; Ma, R.C.; Kong, A.P.; So, W.Y.; Fong, S.Y.Y.; Lam, S.P. Mental morbidities and chronic fatigue in severe acute respiratory syndrome survivors: Long-term follow-up. Arch. Intern. Med. 2009, 169, $2142-2147$. [CrossRef]

19. Desai, S.V.; Law, T.J.; Needham, D.M. Long-term complications of critical care. Crit. Care Med. 2011, 39, 371-379. [CrossRef]

20. Herridge, M.S.; Moss, M.; Hough, C.L.; Hopkins, R.O.; Rice, T.W.; Bienvenu, O.J.; Azoulay, E. Recovery and outcomes after the acute respiratory distress syndrome (ARDS) in patients and their family caregivers. Intensiv. Care Med. 2016, 42, 725-738. [CrossRef]

21. Dinakaran, D.; Manjunatha, N.; Kumar, C.N.; Suresh, B.M. Neuropsychiatric aspects of COVID-19 pandemic: A selective review. Asian J. Psychiatry 2020, 53, 102188. [CrossRef]

22. Liguori, C.; Pierantozzi, M.; Spanetta, M.; Sarmati, L.; Cesta, N.; Iannetta, M.; Ora, J.; Mina, G.G.; Puxeddu, E.; Balbi, O.; et al. Subjective neurological symptoms frequently occur in patients with SARS-CoV2 infection. Brain Behav. Immun. 2020, 88, 11-16. [CrossRef]

23. Vindegaard, N.; Benros, M.E. COVID-19 pandemic and mental health consequences: Systematic review of the current evidence. Brain Behav. Immun. 2020, 89, 531-542. [CrossRef] [PubMed]

24. Nalleballe, K.; Onteddu, S.R.; Sharma, R.; Dandu, V.; Brown, A.; Jasti, M.; Yadala, S.; Veerapaneni, K.; Siddamreddy, S.; Avula, A.; et al. Spectrum of neuropsychiatric manifestations in COVID-19. Brain Behav. Immun. 2020, 88, 71-74. [CrossRef] [PubMed]

25. Varatharaj, A.; Thomas, N.; Ellul, M.A.; Davies, N.W.; Pollak, T.A.; Tenorio, E.L.; Sultan, M.; Easton, A.; Breen, G.; Zandi, M.; et al. Neurological and neuropsychiatric complications of COVID-19 in 153 patients: A UK-wide surveillance study. Lancet Psychiatry 2020, 7, 875-882. [CrossRef]

26. Parra, A.; Juanes, A.; Losada, C.; Álvarez-Sesmero, S.; Santana, V.; Martí, I.; Urricelqui, J.; Rentero, D. Psychotic symptoms in COVID-19 patients. A retrospective descriptive study. Psychiatry Res. 2020, 291, 113254. [CrossRef] [PubMed]

27. Cipriani, G.; Danti, S.; Nuti, A.; Carlesi, C.; Lucetti, C.; Di Fiorino, M. A complication of coronavirus disease 2019: Delirium. Acta Neurol. Belg. 2020, 120, 927-932. [CrossRef] [PubMed]

28. Helms, J.; Kremer, S.; Merdji, H.; Clere-Jehl, R.; Schenck, M.; Kummerlen, C.; Collange, O.; Boulay, C.; Fafi-Kremer, S.; Ohana, M.; et al. Neurologic Features in Severe SARS-CoV-2 Infection. N. Engl. J. Med. 2020, 382, 2268-2270. [CrossRef] [PubMed]

29. Cai, X.; Hu, X.; Ekumi, I.O.; Wang, J.; An, Y.; Li, Z.; Yuan, B. Psychological distress and its correlates among COVID-19 survivors during early convalescence across age groups. Am. J. Geriatr. Psychiatry 2020, 28, 1030-1039. [CrossRef]

30. Yuan, B.; Li, W.; Liu, H.; Cai, X.; Song, S.; Zhao, J.; Hu, X.; Li, Z.; Chen, Y.; Zhang, K.; et al. Correlation between immune response and self-reported depression during convalescence from COVID-19. Brain Behav. Immun. 2020, 88, 39-43. [CrossRef]

31. Batty, G.; Deary, I.; Luciano, M.; Altschul, D.; Kivimäki, M.; Gale, C. Psychosocial factors and hospitalisations for COVID-19: Prospective cohort study based on a community sample. Brain Behav. Immun. 2020, 89, 569-578. [CrossRef]

32. Pinna, P.; Grewal, P.; Hall, J.; Tavarez, T.; Dafer, R.M.; Garg, R.; Osteraas, N.D.; Pellack, D.R.; Asthana, A.; Fegan, K.; et al. Neurological manifestations and COVID-19: Experiences from a tertiary care center at the Frontline. J. Neurol. Sci. 2020, 415, 116969. [CrossRef]

33. Chaumont, H.; San-Galli, A.; Martino, F.; Couratier, C.; Joguet, G.; Carles, M.; Roze, E.; Lannuzel, A. Mixed central and peripheral nervous system disorders in severe SARS-CoV-2 infection. J. Neurol. 2020, 267, 3121-3127. [CrossRef] [PubMed]

34. Rogers, J.P.; Chesney, E.; Oliver, D.; Pollak, T.A.; McGuire, P.; Fusar-Poli, P.; Zandi, M.S.; Lewis, G.; David, A.S. Psychiatric and neuropsychiatric presentations associated with severe coronavirus infections: A systematic review and meta-analysis with comparison to the COVID-19 pandemic. Lancet Psychiatry 2020, 7, 611-627. [CrossRef]

35. Troyer, E.A.; Kohn, J.N.; Hong, S. Are we facing a crashing wave of neuropsychiatric sequelae of COVID-19? Neuropsychiatric symptoms and potential immunologic mechanisms. Brain Behav. Immun. 2020, 87, 34-39. [CrossRef] [PubMed] 
36. Kim, H.-C.; Yoo, S.-Y.; Lee, B.-H.; Lee, S.H.; Shin, H.-S. Psychiatric Findings in Suspected and Confirmed Middle East Respiratory Syndrome Patients Quarantined in Hospital: A Retrospective Chart Analysis. Psychiatry Investig. 2018, 15, 355-360. [CrossRef] [PubMed]

37. Sasannejad, C.; Ely, E.W.; Lahiri, S. Long-term cognitive impairment after acute respiratory distress syndrome: Review of clinical impact and pathophysiological mechanisms. Crit. Care 2019, 23, 352. [CrossRef] [PubMed]

38. Grasselli, G.; Zangrillo, A.; Zanella, A.; Antonelli, M.; Cabrini, L.; Castelli, A.; Cereda, D.; Coluccello, A.; Foti, G.; Fumagalli, R.; et al. Baseline characteristics and outcomes of 1591 patients infected with SARS-CoV-2 admitted to ICUs of the Lombardy Region, Italy. JAMA 2020, 323, 1574-1581. [CrossRef]

39. Hopkins, R.O.; Gale, S.D.; Weaver, L.K. Brain atrophy and cognitive impairment in survivors of acute respiratory distress syndrome. Brain Inj. 2006, 20, 263-271. [CrossRef]

40. Hopkins, R.O.; Weaver, L.K.; Pope, D.; Orme, J.F., Jr.; Bigler, E.D.; Larson-Lohr, V. Neuropsychological sequelae and impaired health status in survivors of severe acute respiratory distress syndrome. Am. J. Respir. Crit. Care Med. 1999, 160, 50-56. [CrossRef]

41. Daroische, R.; Hemminghyth, M.S.; Eilertsen, T.H.; Breitve, M.H.; Chwiszczuk, L.J. Cognitive Impairment After COVID-19-A Review on Objective Test Data. Front. Neurol. 2021, 12, 699582. [CrossRef]

42. Beaud, V.; Crottaz-Herbette, S.; Dunet, V.; Vaucher, J.; Bernard-Valnet, R.; Du Pasquier, R.; Bart, P.-A.; Clarke, S. Pattern of cognitive deficits in severe COVID-19. J. Neurol. Neurosurg. Psychiatry 2021, 92, 567-568. [CrossRef]

43. Negrini, F.; Ferrario, I.; Mazziotti, D.; Berchicci, M.; Bonazzi, M.; de Sire, A.; Negrini, S.; Zapparoli, L. Neuropsychological Features of Severe Hospitalized Coronavirus Disease 2019 Patients at Clinical Stability and Clues for Postacute Rehabilitation. Arch. Phys. Med. Rehabilitation 2021, 102, 155-158. [CrossRef] [PubMed]

44. Manera, M.R.; Fiabane, E.; Pain, D.; Aiello, E.N.; Radici, A.; Ottonello, M.; Padovani, M.; Wilson, B.A.; Fish, J.; Pistarini, C. Clinical features and cognitive sequelae in COVID-19: A retrospective study on N=152 patients. Neurol. Sci. 2021, 43, 45-50. [CrossRef] [PubMed]

45. García-Molina, A.; Espiña-Bou, M.; Rodríguez-Rajo, P.; Sánchez-Carrión, R.; Enseñat-Cantallops, A. Neuropsychological rehabilitation program for patients with post-COVID-19 syndrome: A clinical experience. Neurología 2021, 36, 565-566. [CrossRef]

46. Mishra, R.; Banerjea, A.C. Neurological Damage by Coronaviruses: A Catastrophe in the Queue! Front. Immunol. 2020, 11, 565521. [CrossRef] [PubMed]

47. Zubair, A.S.; McAlpine, L.S.; Gardin, T.; Farhadian, S.; Kuruvilla, D.E.; Spudich, S. Neuropathogenesis and neurologic manifestations of the Coronaviruses in the age of Coronavirus disease 2019: A review. JAMA Neurol. 2020, 77, 1018-1027. [CrossRef]

48. Hoffmann, M.; Kleine-Weber, H.; Schroeder, S.; Krüger, N.; Herrler, T.; Erichsen, S.; Schiergens, T.S.; Herrler, G.; Wu, N.H.; Nitsche, A.; et al. SARS-CoV-2 cell entry depends on ACE2 and TMPRSS2 and is blocked by a clinically proven protease inhibitor. Cell 2020, 181, 271-280.e8. [CrossRef]

49. Xia, H.; Lazartigues, E. Angiotensin-converting enzyme 2 in the brain: Properties and future directions. J. Neurochem. 2008, 107, 1482-1494. [CrossRef]

50. Netland, J.; Meyerholz, D.K.; Moore, S.; Cassell, M.; Perlman, S. Severe Acute Respiratory Syndrome Coronavirus Infection Causes Neuronal Death in the Absence of Encephalitis in Mice Transgenic for Human ACE2. J. Virol. 2008, 82, 7264-7275. [CrossRef]

51. Poyiadji, N.; Shahin, G.; Noujaim, D.; Stone, M.; Patel, S.; Griffith, B. COVID-19-associated Acute Hemorrhagic Necrotizing Encephalopathy. Radiology 2020, 296, E119-E120. [CrossRef]

52. Egbert, A.R.; Cankurtaran, S.; Karpiak, S. Brain abnormalities in COVID-19 acute/subacute phase: A rapid systematic review. Brain Behav. Immun. 2020, 89, 543-554. [CrossRef]

53. Maiese, A.; Manetti, A.C.; Bosetti, C.; Del Duca, F.; La Russa, R.; Frati, P.; Di Paolo, M.; Turillazzi, E.; Fineschi, V. SARS-CoV-2 and the brain: A review of the current knowledge on neuropathology in COVID-19. Brain Pathol. 2021, 31, e13013. [CrossRef] [PubMed]

54. Coolen, T.; Lolli, V.; Sadeghi, N.; Rovai, A.; Trotta, N.; Taccone, F.S.; Creteur, J.; Henrard, S.; Goffard, J.-C.; De Witte, O.; et al. Early postmortem brain MRI findings in COVID-19 non-survivors. Neurology 2020, 95, e2016-e2027. [CrossRef] [PubMed]

55. Solomon, I.H.; Normandin, E.; Bhattacharyya, S.; Mukerji, S.S.; Keller, K.; Ali, A.S.; Adams, G.; Hornick, J.L.; Padera, R.F., Jr.; Sabeti, P. Neuropathological Features of Covid-19. N. Engl. J. Med. 2020, 383, 989-992. [CrossRef] [PubMed]

56. Matschke, J.; Lütgehetmann, M.; Hagel, C.; Sperhake, J.P.; Schröder, A.S.; Edler, C.; Mushumba, H.; Fitzek, A.; Allweiss, L.; Dandri, M.; et al. Neuropathology of patients with COVID-19 in Germany: A post-mortem case series. Lancet Neurol. 2020, 19, 919-929. [CrossRef]

57. Frank-Cannon, T.C.; Alto, L.T.; McAlpine, F.E.; Tansey, M.G. Does neuroinflammation fan the flame in neurodegenerative diseases? Mol. Neurodegener. 2009, 4, 47. [CrossRef]

58. Dantzer, R. Neuroimmune Interactions: From the Brain to the Immune System and Vice Versa. Physiol. Rev. 2018, 98, 477-504. [CrossRef]

59. Chen, G.; Wu, D.; Guo, W.; Cao, Y.; Huang, D.; Wang, H.; Wang, T.; Zhang, X.; Chen, H.; Yu, H.; et al. Clinical and immunological features of severe and moderate coronavirus disease 2019. J. Clin. Investig. 2020, 130, 2620-2629. [CrossRef]

60. Huang, C.; Wang, Y.; Li, X.; Ren, L.; Zhao, J.; Hu, Y.; Zhang, L.; Fan, G.; Xu, J.; Gu, X.; et al. Clinical features of patients infected with 2019 novel coronavirus in Wuhan, China. Lancet 2020, 395, 497-506. [CrossRef] 
61. Clark, I.A.; Vissel, B. The meteorology of cytokine storms, and the clinical usefulness of this knowledge. Semin. Immunopathol. 2017, 39, 505-516. [CrossRef]

62. Kuno, R.; Wang, J.; Kawanokuchi, J.; Takeuchi, H.; Mizuno, T.; Suzumura, A. Autocrine activation of microglia by tumor necrosis factor- $\alpha$. J. Neuroimmunol. 2005, 162, 89-96. [CrossRef]

63. Perry, V.H.; Teeling, J. Microglia and macrophages of the central nervous system: The contribution of microglia priming and systemic inflammation to chronic neurodegeneration. Semin. Immunopathol. 2013, 35, 601-612. [CrossRef] [PubMed]

64. Akiyama, H.; Barger, S.; Barnum, S.; Bradt, B.; Bauer, J.; Cole, G.M.; Cooper, N.R.; Eikelenboom, P.; Emmerling, M.; Fiebich, B.L.; et al. Inflammation and Alzheimer's disease. Neurobiol. Aging 2000, 21, 383-421. [CrossRef]

65. Walker, K.A.; Gottesman, R.F.; Wu, A.; Knopman, D.S.; Gross, A.L.; Mosley, T.H.; Selvin, E.; Windham, B.G. Systemic inflammation during midlife and cognitive change over 20 years: The ARIC Study. Neurology 2019, 92, e1256-e1267. [PubMed]

66. Sy, M.; Kitazawa, M.; Medeiros, R.; Whitman, L.; Cheng, D.; Lane, T.E.; LaFerla, F.M. Inflammation induced by infection potentiates tau pathological features in transgenic mice. Am. J. Pathol. 2011, 178, 2811-2822. [CrossRef] [PubMed]

67. Koenigsknecht-Talboo, J.; Landreth, G.E. Microglial phagocytosis induced by fibrillar beta-amyloid and IgGs are differentially regulated by proinflammatory cytokines. J. Neurosci. 2005, 25, 8240-8249. [CrossRef]

68. Miners, S.; Kehoe, P.G.; Love, S. Cognitive impact of COVID-19: Looking beyond the short term. Alzheimer's Res. Ther. 2020, 12, 1-16. [CrossRef]

69. Fotuhi, M.; Mian, A.; Meysami, S.; Raji, C.A. Neurobiology of COVID-19. J. Alzheimer's Dis. 2020, 76, 3-19. [CrossRef]

70. Wang, F.; Kream, R.M.; Stefano, G.B. Long-Term Respiratory and Neurological Sequelae of COVID-19. Med Sci. Monit. 2020, 26, 928996. [CrossRef]

71. Kaczmarek-Hajek, K.; Zhang, J.; Kopp, R.; Grosche, A.; Rissiek, B.; Saul, A.; Bruzzone, S.; Engel, T.; Jooss, T.; Krautloher, A.; et al. Re-evaluation of neuronal P2X7 expression using novel mouse models and a P2X7-specific nanobody. eLife 2018, 7, 36217. [CrossRef]

72. Andrejew, R.; Oliveira-Giacomelli, Á.; Ribeiro, D.E.; Glaser, T.; Arnaud-Sampaio, V.F.; Lameu, C.; Ulrich, H. The P2X7 Receptor: Central Hub of Brain Diseases. Front. Mol. Neurosci. 2020, 13, 124. [CrossRef]

73. Ribeiro, D.E.; Roncalho, A.L.; Glaser, T.; Ulrich, H.; Wegener, G.; Joca, S. P2X7 Receptor Signaling in Stress and Depression. Int. J. Mol. Sci. 2019, 20, 2778. [CrossRef]

74. Ribeiro, D.E.; Oliveira-Giacomelli, Á.; Glaser, T.; Arnaud-Sampaio, V.F.; Andrejew, R.; Dieckmann, L.; Baranova, J.; Lameu, C.; Ratajczak, M.Z.; Ulrich, H. Hyperactivation of P2X7 receptors as a culprit of COVID-19 neuropathology. Mol. Psychiatry 2021, 26, 1044-1059. [CrossRef]

75. Di Virgilio, F.; Tang, Y.; Sarti, A.C.; Rossato, M. A rationale for targeting the P2X7 receptor in Coronavirus disease 19. J. Cereb. Blood Flow Metab. 2020, 177, 4990-4994. [CrossRef]

76. Kuo, C.L.; Pilling, L.C.; Atkins, J.L.; Masoli, J.A.; Delgado, J.; Kuchel, G.A.; Melzer, D. ApoE e4e4 genotype and mortality with COVID-19 in UK Biobank. J. Gerontol. A Biol. Sci. Med. Sci. 2020, 75, 1801-1803. [CrossRef]

77. Kehoe, P.G.; Wong, S.; Al Mulhim, N.; Palmer, L.E.; Miners, J.S. Angiotensin-converting enzyme 2 is reduced in Alzheimer in association with increasing amyloid-B and tau pathology. Alzheimer's Res. Ther. 2016, 8, 50. [CrossRef]

78. Szcześniak, D.; Gładka, A.; Misiak, B.; Cyran, A.; Rymaszewska, J. The SARS-CoV-2 and mental health: From biological mechanisms to social consequences. Prog. Neuropsychopharmacol. Biol. Psychiatry 2021, 104, 110046. [CrossRef] 